PEMBELAJAR: Jurnal Ilmu Pendidikan, Keguruan, dan Pembelajaran

Volume 5 Nomor 1 April 2021

e-ISSN: 2549-9114 dan p-ISSN: 2549-9203

(Received: Februari-2021; Reviewed: Maert-2021; Published: April 2021)

DOI: https://doi.org/10.26858/pembelajar.v5i1.14694

\title{
Peran Orang Tua Dalam Membantu Belajar Anak di Masa Pandemi Covid-19
}

\author{
Mar'atus Sholikah', Umi Hanifah' \\ ${ }^{12}$ Fakultas Tarbiyah dan Keguruan, UIN Sunan Ampel, Indonesia \\ Corresponding e-mail: maratus14sholikah@gmail.com
}

\begin{abstract}
Abstrak: Penelitian ini memberikan gambaran mengenai peran sentral orang tua dalam membantu belajar anak di masa pandemi covid-19. Pelajaran di rumah tidak akan dapat berjalan efektif tanpa dukungan dan partisipasi aktif orang tua dalam membantu belajar anak. Penelitian ini bisa dijadikan pedoman bagi orang tua yang merasa kesulitan dalam membantu belajar anak di rumah. Metode penelitian yang digunakan adalah deskriptif kualitatif dengan pendekatan studi literatur. Prosedur penelitian diawali dengan mengumpulkan sejumlah informasi yang relevan dengan masalah yang diteliti kemudian direduksi dan dianalisis sehingga mendapatkan kesimpulan yang tepat. Hasil penelitian menunjukkan bahwa peran orang tua dalam membantu anak ada lima yaitu fasilisator, pendamping, guru atau pembimbing, motivator dan director atau pengarah. Kelima peran tersebut harus dijalankan orang tua dengan baik sehingga pembelajaran dari rumah memiliki keefektifan yang sama dengan pembelajaran di sekolah.
\end{abstract}

Kata Kunci : Peran Orang Tua, Belajar Anak, Pandemi, Covid-19

\begin{abstract}
This study provides an overview of the central role of parents in helping children's learning during the co-19 pandemic. Home learning will not be effective without the support and active participation of parents in helping children's learning. This research can be used as a guide for parents who find it difficult to help children's learning at home. The research method used is descriptive qualitative study literature approach. The research procedure begins by gathering a number of information relevant to the problem under study and then reduced and analyzed so that it gets the right conclusions. The results showed that the role of parents in helping children there are five, namely the facilitator, companion, teacher or supervisor, motivator and director or director. The five roles must be carried out by parents well so that learning from home has the same effectiveness as learning in school.
\end{abstract}

Keywords : Role of Parents, Child Learning, Pandemic, Covid-19

(C)2021 -Ini adalah artikel dengan akses terbuka dibawah licenci CC BY-NC-4.0

(https://creativecommons.org/licenses/by-nc/4.0/) by penulis.

\section{PENDAHULUAN}

Covid-19 atau Coronavirus Disease merupakan penyakit yang disebabkan oleh virus SARS-CoV-2 yang terdapat dalam golongan Coronavirus (Yuliana, 2020, p. 187). Golongan Coronavirus biasanya menginfeksi saluran pernafasan, hati dan saraf pada hewan liar. Tetapi dalam perkembangannya virus ini mengalami mutasi genetika sehingga dapat menginfeksi manusia.
Virus SARS-CoV-2 memiliki sifat mudah sekali menular dari satu manusia ke manusia lainnya melalui droplet yaitu tetesan air dari hidung atau mulut (Handayani et al, 2019, 122). Penularan virus bisa terjadi saat droplet dari pembawa virus jatuh di benda yang sering tersentuh oleh orang-orang di sekitarnya. Orang yang menyentuhnya kemudian menyentuh mata, hidung atau mulutnya dapat tertular virus SARSCoV-2. Penularan juga bisa terjadi saat orang yang terjangkit virus sedang batuk atau bersin kemudian terhirup oleh orang yang sehat. Selain 
itu virus SARS-CoV-2 juga mudah sekali berkembang biak (berreplikasi) pada tubuh manusia (Ahsan et al, 2020, p.3).

Gejala yang dialami oleh pasien covid19 pun sulit di deteksi karena virus SARS-CoV2 menginfeksi saluran pernafasan bagian atas dan bagian bawah. Gejala umum orang yang terinfeksi covid-19 sama halnya dengan orang yang mengalami flu biasa seperti demam dan batuk. Kemudian saat virus masuk rongga dalam paru-paru akan menyebabkan gejala lebih parah seperti kesulitan bernafas. Ini merupakan hipotesis awal mengenai proses infeksi virus SARS-CoV-2 ke dalam tubuh manusia (Arnani. Melani, 2020).

Covid-19 pertama kali ditemukan di Wuhan, China pada akhir tahun 2019. Dalam waktu kurang dari 30 hari terdapat 550 orang telah terinfeksi dan 17 orang meninggal. Penyakit covid-19 juga menyebar hingga ke luar China. WHO mengumumkan kasus pertama di Thailand pada tanggal 13 Januari 2020 dan pada tanggal 21 Januari 2020 virus corona telah menyebar ke benua Amerika. Penyebaran corona yang makin meluas ini membuat WHO menyatakan penyakit covid-19 sebagai pandemi (Redaksi, 2020).

Di Indonesia kasus pertama covid-19 diumumkan oleh Presiden Jokowi pada tanggal 2 Maret 2020. Presiden Jokowi mengkonfirmasi ada 2 pasien terjangkit virus corona. Kedua pasien tersebut berasal dari satu keluarga dan berjenis kelamin perempuan. Mereka diduga tertular akibat berinteraksi langsung dengan warga negara asing (Ihsanuddin, 2020). Dengan adanya virus covid-19 di Indonesia, Pemerintah segera mengeluarkan berbagai kebijakan di berbagai sektor (ekonomi, sosial, pendidikan dan agama/ibadah) untuk mencegah penyebaran virus corona semakin meluas.

Di dunia pendidikan, Nadiem Anwar Makariem selaku Menteri Pendidikan dan Kebudayaan (Mendikbud) mengeluarkan dua surat edaran. Pertama dikeluarkannya Surat Edaran Nomor 2 Tahun 2020 tentang Pencegahan dan Penanganan Covid-19 di lingkungan Kemendikbud. Dan yang kedua Surat Edaran Nomor 3 Tahun 2020 tentang Pencegahan Covid19 di Satuan Pendidikan.

Nadiem juga menghimbau kepada Kepala Dinas Pendidikan Provinsi dan Kabupaten/Kota, Kepala Lembaga Layanan Pendidikan Tinggi, Pimpinan Perguruan Tinggi, Pimpinan Perguruan Tinggi, Kepala Sekolah di seluruh Indonesia untuk melakukan langkahlangkah pencegahan Covid-19 di Lingkungan
Pendidikan. Informasi ini disampaikannya melalui siaran pers nomor : 048/SIPRES/A6/III/2020 di kantor Kemendikbud, jakarta pada Rabu (11/03/2020) (Paembon. Andika, 2020).

Gubenur Jawa Timur Khofifah Indar Parawansa langsung menanggapi himbauan kemendikbud dengan melakukan Rapat Koordinasi Teknis dengan jajaran Forkompimda Jatim di Gedung Negara Grahadi Surabaya pada Minggu (15/03/2020). Rapat ini berujuan untuk menemukan langkah yang tepat untuk mencegah penyebaran covid-19 semakin meluas di wilayah Jawa Timur. Salah satu hasil kesepakatan yang dicapai di bidang pendidikan adalah mengganti proses pembelajaran di sekolah menjadi belajar dari rumah. Keputusan ini diumumkan Ibu Khofifah melalui akun instagram pribadinya berupa foto tulisan tangan asli dirinya.

Keputusan yang dikeluarkan oleh Ibu khofifah ini sejalan dengan Surat Edaran Nomor 4 Tahun 2020 Tentang Pelaksanaan Kebijakan Pendidikan Dalam Masa Darurat Penyebaran Coronavirus Disease (covid-19) yang dikeluarkan oleh Kemendikbud pada tanggal 24 maret 2020. Isinya menjelaskan tentang pembatalan UN di semua tingkat pendidikan, ketentuan proses belajar dari rumah, ketentuan ujian sekolah untuk kelulusan, ketentuan kenaikan kelas dan ketentuan pelaksanaan Penerimaan Peserta Didik Baru (PPDB).

Awalnya program ini hanya dijalankan dalam kurun waktu 2 minggu. Akan tetapi, kurva jumlah pasien covid-19 yang semakin bertambah di daerah Jawa Timur memaksa Ibu Khofifah untuk memperpanjang program belajar dari rumah hingga saat ini.

Program belajar dari rumah merupakan program yang baru di Indonesia. Pasalnya lembaga pendidikan biasanya hanya menggunakan pembelajaran konvensional melalui tatap muka di sekolah dengan tambahan tugas yang dikerjakan di rumah. Pemerintah berharap program ini bisa berjalan dengan baik dan memiliki efektifitas yang sama dengan kegiatan pembelajaran di sekolah. Oleh karena itu butuh dukungan dan partisipasi aktif dari seluruh elemen yang terlibat di dalamnya termasuk orang tua. Peran vital orang tua (wali murid) menjadi salah satu kunci sukses dalam pembelajaran daring selain kreativitas guru dan motivasi belajar anak (Kemendikbud, 2020).

Program yang telah dijalankan selama kurang lebih 5 bulan ini membawa pro dan kontra di kalangan masyarakat terutama yang memiliki 
anak di usia sekolah. Pihak pro setuju dengan adanya program ini dikarenakan bisa meminimalisis persebaran covid-19 di Indonesia dan mencegah generasi muda terinfeksi covid-19. Di sisi lain merasa jika program ini tidak efektif untuk diterapkan yang hanya membuat anak semakin bodoh dan malas belajar.

Pernyataan itu dilontarkan oleh orang tua peserta didik dikarenakan durasi pembelajaran jarak jauh yang relatif singkat sehingga banyak waktu senggang yang dipergunakan anak untuk bermain. Selain itu kendala jaringan internet yang dapat dialami oleh peserta didik menyebabkan proses transfer of knowladge tidak dapat berjalan maksimal.

Proses pembelajaran yang kurang optimal memaksa orang tua untuk mengulang kembali materi pembelajaran yang telah disampaikan oleh gurunya. Kegiatan ini juga tidak dapat berjalan dengan mulus disebabkan minimnya pengetahuan yang dimiliki orang tua terhadap materi pembelajaran. Kondisi ini membuat stress para orang tua peserta didik.

Stress tidak hanya dirasakan oleh orang tua melainkan juga pada peserta didik. Dilansir dari republika.co.id, Komisi Perlindungan Anak Indonesia (KPAI) menerima pengaduan dari sejumlah orang tua siswa yang mengeluhkan tugas-tugas yang dibagikan guru kepada anakanaknya secara daring. Anak-anak mengalami stress akibat tugas yang dibebankan gurunya setiap hari dengan waktu pengerjaan kurang lebih satu jam (Rezkisari. Indra, 2020).

Anak juga seringkali merasakan malas dan bosan dengan pembelajaran jarak jauh yang menggunakan metode itu-itu saja. Mereka mengatakan rindu belajar di sekolah dan ingin bertemu dengan teman-temannya. Orang tua tidak bisa berbuat apa-apa selain membujuknya untuk tetap belajar dengan janji akan membelikannya snack setelah mengikuti pembelajaran.

Problematika yang telah dipaparkan di atas menunjukkan bahwa orang tua kurang bisa memahami perannya dalam membantu belajar anak di rumah. Mereka terbiasa mengadalkan guru dalam memberikan pengetahuan kepada anaknya. Sehingga pengetahuan yang dimiliki anak menjadi terbatas.

Orang tua seharusnya membantu guru dalam memberikan pengetahuan atau informasi kepada anak. Dikarenakan orang tua memiliki waktu yang tak terbatas bersama anak. Padahal keefektifan pembelajaran jarak jauh juga ditentukan oleh peran sinergis orang tua.

Dengan adanya permasalah di atas, penulis ingin mengumpulkan sejumlah informasi yang dapat digunakan sebagai pedoman bagi orang tua dalam membantu belajar anak di rumah.

\section{METODE}

Penelitian ini menggunakan metode penelitian deskriptif kualitatif. Penelitian deskriptif kualitatif adalah pengambaran fakta, data atau objek material berupa bahasa melalui interpretasi yang tepat dan sistematis (Wibowo. Wahyu, 2011, p.43). Jenis penelitiannya ialah fenomenologi. Fenomenologi ialah penelitian yang berusaha untuk menemukan makna mendasar dan esensi dari suatu peristiwa atau pengalaman yang dialami oleh objek penelitian. Jenis penelitian ini cocok digunakan oleh peneliti karena membahas mengenai peran orang tua dalam membantu belajar anak di masa pandemi covid-19.

Teknik penggumpulan data dilakukan dengan studi kepustakaan. Studi kepustakaan merupakan serangkaian kegiatan ilmiah yang dilakukan dengan mengumpulkan sejumlah informasi yang relevan dengan topik atau masalah yang akan atau sedang dikaji dengan kepustakaan sebagai sumber utama refrensi (I Made \& Cahyaningrum, 2020, p. 26). Informasi tersebut diperoleh melalui naskah yang telah informasi yang dipublikasikan dalam bentuk buku, jurnal ilmiah, surat kabar, website, dan lain-lain

Prosedur penelitiannya terdiri dari identifikasi teori secara sistematis dan menemukan pustaka, dan analisis dokumen serta menarik kesimpulan yang tepat untuk memecahkan persoalan yang di teliti (Hermawan,2020, p. 18).

\section{PEMBAHASAN}

\subsection{Pembelajaran Jarak Jauh}

Pembelajaran jarak jauh awalnya dikembangkan di Amerika Serikat (USA), Prancis, Jerman dan Inggris sekitar tahun 1800. Kala itu, Sir Isac Pitman mengajar jarak jauh menggunakan surat. Dan pada tahun 1980 an, International Coresspondence School (ICS) membangun sistem perkuliahan home-sudy 
course yang merupakan cikal bakal dari sistem pembelajaran jarak jauh yang digunakan sekarang yaitu E-learning(Taufik, 2019, p.88).

Di tengah pandemi ini, Indonesia menerapkan program belajar dari rumah yang dilaksanakan menggunakan pembelajaran jarak jauh (PJJ). Pelaksanaan belajar dari rumah bertujuan untuk memenuhi hak peserta didik untuk tetap mendapatkan pendidikan di era pandemi covid-19. Prinsip pelaksanaan belajar dari rumah yaitu :

a Keselamatan dan kesehatan lahir batin seluruh warga satuan pendidikan termasuk kepala sekolah, guru dan staf karyawan serta peserta didik merupakan alasan utama dilaksanaknnya belajar dari rumah (BDR).

b Tujuan dilaksanakan BDR adalah untuk memberikan pengalaman belajar yang bermanfaat bagi peserta didik tanpa terbebani dengan capaian kurikulum.

c Pelakasanaan BDR dapat difokuskan pada pendidikan kecakapan hidup antara lain mengenai pandemi covid-19.

d Materi pendidikan disesuaikan dengan usia dan jenjang pendidikan, konteks budaya, karakter dan jurusan peserta didik (bagi SMA/Sederajat).

e Pelaksanaan dan penugasan BDR dapat bervariasi antar daerah tergantung satuan pendidikan dan mempertimbangkan kesenjangan akses dan fasilitas BDR.

f Hasil belajar peserta didik selama BDR diberi umpan balik yang bersifat kualitatif dan berguna tanpa harus memberikan nilai kuantitatif.

g Mengutamakan interaksi dan komunikasi yang positif antara guru dengan orang tua/wali.

Dalam Surat Edaran Nomor 15 Tahun 2020 dijelaskan bahwa pembelajaran jarak jauh yang dilaksanakan di Indonesia menggunakan dua pendekatan antara lain:

a Pembelajaran jarak jauh dalam jaringan (daring)

Pembelajaran daring adalah pembelajaran yang dilakukan secara virtual (dunia maya) dengan memanfaatkan koneksi internet (online). Pembelajaran daring yang dilaksanakan di Indonesia terbagi menjadi dua yaitu tatap muka virtual dan Learning Managemen System (LMS). Tatap muka virtual bertujuan untuk memastikan interaksi secara langsung antara pendidik dan peserta didik. Aplikasi yang digunakan dalam tatap muka yaitu video conference, teleconfrence dan diskusi melaui group media sosial dan personal chat.

Learning Managemen System (LMS) adalah sistem pengelolaan pembelajaran yang terkoneksi internet. Aktivitas dalam LMS adalah pemberian materi, soal dan pengumpulan tugas. Aplikasi yang digunakan ialah google clasroom, schoologi, edmodo, dan lain sebagainya.

Pembelajaran daring ini membutuhkan perangkat elektronik (handphone, tablet, laptop) dan kuota internet. Kemampuan mengoperasikan perangkat elektronik menjadi bagian terpenting dalam pembelajaran daring. Perangkat elektronik yang canggih dan kuota internet yang memenuhi tanpa adanya kemampuan mengoperasikannya dengan baik maka hal itu sia-sia.

b Pembelajaran jarak jauh luar daringan (luring)

Pembelajaran luring adalah pembelajaran yang tidak membutuhkan koneksi internet (offline). Pembelajaran luring menggunakan media buku, modul, bahan ajar dari lingkungan sekitar, media televisi dan radio. Media buku dan modul biasanya sudah disediakan oleh pihak sekolah sementara media televisi dan radio merupakan fasilitas yang harus dipenuhi oleh orang tua (Kebudayaan, 2020, p.2-3).

Setiap satuan lembaga pendidikan dapat memilih satu atau menggabungkan kedua pendekatan di atas disesuaikan dengan ketersediaan dan kesiapan sarana prasana serta kondisi geografis sekolah. Apabila satuan lembaga pendidikan belum siap untuk melaksanakan pembelajaran daring maka mereka bisa menggunakan pembelajaran luring. Jika satuan memiliki sarana dan prasarana yang memadai maka diperbolehkan mengkombinasi kedua pendekatan tersebut.

\subsection{Peran Orang Tua dalam Pembelajaran Jarak Jauh}

Pembelajaran jarak jauh yang dilaksanakan melalui program belajar dari rumah membutuhkan peran signifikan orang tua untuk menunjang keefektifitas pembelajaran. Berikut 
beberapa peran orang tua dalam membantu belajar anak di rumah yaitu :

\subsubsection{Orang tua sebagai Fasilisator}

Fasilitas yang lengkap dapat mempermudah anak dalam mengikuti pembelajaran. Orang tua sebagai fasilisator hendaknya berusaha untuk memenuhi segala kebutuhan yang diperlukan anak dalam mengikuti pembelajaran jarak jauh.

Dalam pembelajaran daring, fasilitas yang dibutuhkan anak berupa alat elektronik (gadget, laptop,tablet,PC) dan kuota internet. Kebutuhan ini merupakan kebutuhan pimer yang harus bisa dipenuhi oleh orang tua karena ini merupakan inti dari pembelajaran jarak jauh yang sebagian besar menggunakan pembelajaran daring.

Untuk pembelajaran luring menggunakan televisi/radio, kemungkinan tidak ada kendala yang besar. Hal ini dikarenakan hampir semua rumah memiliki televisi atau radio. Untuk pembelajaran luring yang menggunakan buku atau modul dan bahan ajar biasanya sudah disediakan oleh sekolah sehingga orang tua tidak perlu mengeluarkan biaya lagi. Buku tulis dan bulpoin tetap harus disediakan untuk mencatat hal-hal yang penting sebagai hasil ringkasan dalam pembelajaran jarak jauh yang telah dilaksanakan.

Selain fasilitas di atas, orang tua juga perlu menyediakan ruang belajar yang kondusif dan nyaman bagi anak. Ruang belajar yang kondusif dapat mempengaruhi konsentrasi belajar anak, menghindari anak dari kejuhan, dan kelelahan psikis. Sehingga dapat menumbuhkan motivasi belajar dan meningkatkan prestasi anak (Arianti, 2019, p.61).

\subsubsection{Orang tua sebagai Pedamping}

Di dalam Surat Edaran Nomor 15 Tahun 2020 yang diterbitkan oleh Kemendikbud telah memberikan gambaran mengenai peran orang tua/wali peserta didik dalam pelaksanaan belajar dari rumah. Orang tua/wali murid dalam SE ini berperan sebagai pendamping dalam pembelajaran daring maupun luring yang dilakukan oleh anak. Pendampingan ini dilakukan untuk memastikan anak tetap fokus dan membantu jika ada kendala teknis yang dialami anak ketika pelaksanaan pembelajaran jarak jauh. Pedampingan yang dilakukan oleh orang tua dibagi menjadi tiga bagian yaitu :

a Pendampingan Sebelum Pembelajaran

Ada beberapa hal yang perlu dilakukan oleh orang tua sebelum anaknya melaksanakan pembelajaran, diantaranya yaitu :

1) Orang tua memiliki atau menyimpan nomer telepon/WA setiap guru yang mengajar anaknya.

2) Orang tua wajib bergabung dengan grup yang telah dibentuk oleh guru mata pelajaran atau bisa bergabung dengan grup wali murid yang setingkat dengan kelas anaknya.

3) Orang tua dapat berdiskusi dengan guru mengenai materi yang akan diajarkan kepada anaknya sebelum pembelajaran dilaksankan.

4) Orang tua dapat mengambil bahan ajar ke satuan pendidikan yang ditempati anaknya sesuai waktu yang dijadwalkan untuk pembelajaran luring.

5) Orang tua diharap mengetahui jadwal pembelajaran yang disiarkan melalui TV atau Radio.

6) Orang tua dapat mencari bahan bacaan dari internet untuk menambah pengetahuan peserta didik.

7) Orang tua dapat mengingatkan jadwal pembelajaran daring maupun luring yang akan dilaksanakan oleh anaknya.

8) Mempersiapakan fasilitas yang dibutuhkan dan ruangan yang kondusif untuk pembelajaran daring maupun luring.

9) Orang tua memastikan peserta didik siap untuk mengikuti pembelajaran. Seperti menyuruhnya mandi dan sarapan terlebih dahulu sebelum mengikuti pembelajaran.

b Pendampingan Saat Pembelajaran

Pendampingan orang tua/wali murid pada saat pembelajaran juga diperlukan. Hal ini untuk mencegah anak bermalas-malasan atau malah bermain game online. Beberapa tindakan yang bisa dilakukan orang tua pada saat pembelajaran daring maupun luring, sebagai berikut.

1) Orang tua mengingatkan anak untuk selalu berdoa sebelum dan sesudah belajar. 
2) Orang tua mendampingi dan memantau proses pembelajaran.

3) Orang tua mendorong anaknya agar aktif selama proses pembelajaran.

4) Orang tua membantu teknis dalam mengoperasikan aplikasi dan teknologi elektronik.

5) Orang tua memastikan anaknya mengikuti pembelajaran dengan nyaman dan gembira.

6) Orang tua membantu proses pembelajaran luring sesuai yang dijadwalkan dan penugasan yang telah diberikan. Misalnya guru memberikan tugas kepada muridnya untuk mempelajari buku halaman 98 dan mengerjakan soal latihan halaman 107. Ini dikategorikan dalam pembelajaran luring. Orang tua dapat membantu anaknya dalam memahami materi dan mengerjakan soal latihan tersebut.

c Pendampingan Sesudah Pembelajaran.

1) Orang tua dapat mengisi lembar pemantauan pembelajaran (jika ada).

2) Orang tua membantu dan memastikan anak mengumpulkan tugas tepat waktu (jika ada).

3) Orang tua dapat mengirim foto dokumentasi yang menunjukkan anak belajar secara luring jika diminta oeh guru (Kebudayaan, 2020, p.16-17).

\subsubsection{Orang tua sebagai Guru}

Setelah mengikuti pembelajaran online bersama guru terkadang anak mengalami kesulitan dalam memahami materi pembelajaran yang telah diajarkan kepadannya. Hal ini bisa disebabkan karena pembelajaran daring yang relatif singkat dan tidak ada pengulangan materi dari guru.

Kondisi ini juga sering dialami pada saat pembelajaran di sekolah. Umumnya solusi yang diambil oleh orang tua mengatasi masalah di atas adalah mengirimkan anaknya untuk mendapatkan tambahan jam belajar di Lembaga Bimbingan Belajar (LBB) yang ada di sekitar rumahnya. Akan tetapi solusi tersebut tidak dapat direalisasikan di masa pandemi sekarang ini.

Oleh karena itu orang tua dituntut untuk serba-bisa dalam berbagai mata pelajaran selama belajar dari rumah. Jika orang tua kurang mengerti mengenai pokok pembelajaran anaknya, orang tua dapat mencari pemacahannya melalui internet atau berdiskusi langsung dengan guru mata pelajaran melalui media sosial untuk menemukan solusi yang tepat. Dan ketika orang tua sudah memahami pokok pembelajarannya maka orang tua bisa menyampaikan materi tersebut kepada anaknnya.

Sebelum orang tua mengajarkan materi kepada anaknya, alangkah baiknya orang tua mengerti gaya belajar yang sesuai dengan kepribadian dan minat anak (Ahsani, 2020, p. 43). Penerapan gaya belajar yang sesuai dengan karakter anak akan mempermudah penyerapan informasi yang diberikan. Ada tiga jenis gaya belajar anak yang perlu orang tua ketahui, diantaranya yaitu :

a Visual

Gaya belajar visual menitikberatkan pada penglihatan. Anak dapat mudah menyerap dan memahami informasi dengan melihat. Mereka bisa memaksimalkan kemampuannya dengan memperhatikan gambar-gambar. Cara orang tua dalam mengajari anak dengan gaya belajar visual adalah memberikannya buku bergambar, memutarkan tayangan televisi atau video edukasi, dan buatlah chart dengan foto untuk mempermudahnya dalam menyerap informasi yang telah Anda berikan. Beberapa karakteristik seorang anak yang memiliki gaya belajar visual yaitu :

1) Mudah terpesona dengan gambargambar, ilustrasi, tayangan televisi atau video,

2) Mudah mengingat cara orang lain melakukan sesuatu, dan

3) Sangat cepat mengingat bentuk,warna, dan huruf.

b Audiotorial

Gaya belajar audiotorial yaitu gaya belajar yang mengadalkan pendengarannya untuk menyerap dan memahami informasi. Orang tua dapat menggunakan metode bercerita, berbicara atau berdiskusi, menghafal lirik lagu yang berhubungan dengan materi pembelajaran anak. Anak yang memiliki gaya belajar audiotorial membutuhkan tempat yang tenang untuk fokus belajar. Beberapa karakteristik yang dimiliki anak dengan gaya belajar audiotorial yaitu :

1) Mudah mengingat cerita atau lagu yang pernah ia dengarkan.

2) Dapat mengikuti dan memahami arahan dengan mudah.

3) Mampu mengulangi kalimat atau komentar yang didengarkannya. 
4) Senang dibacakan apapun termasuk cerita.

5) Suka mengkomunikasikan ide-idenya secara verbal.

6) Tertarik dengan kegiatan yang berbau diskusi atau debat.

7) Menyukai seni musik.

8) Tidak tertarik membaca buku tapi suka jika dibacakan.

9) Mudah menangkat informasi yang disampaikan secara verbal, meski anak kelihatannya tidak memperhatikan.

\section{c Kinestetik}

Gaya belajar kinestik adalah gaya belajar yang dilakukan dengan bergerak, berbuat dan menyentuh sesuatu untuk dapat menyerap dan memahami informasi (Widayanti, 2013, p.11). Bagi orang tua yang memiliki anak dengan gaya belajar kinestetik diharapkan untuk selalu bersabar. Terkadang bila orang tua mengajarinya sesuatu anak tidak bisa duduk dengan tenang bahkan berlari-lari. Itu merupakan hal yang biasa dilakukannya untuk dapat memahami informasi. Orang tua bisa membantu belajarnya dengan mengajaknya berpartisipasi dengan menirukan gerakangerakan yang Anda bacakan, menciptakan permainan-permainan gerakan, dan mengajaknya bermain role-play (Dini, 2020). Beberapa karakteristik yang dimiliki anak dengan gaya belajar audiotorial yaitu :

1) Senang bermain peran atau menirukan gerakan-gerakan yang mengambarkan apa yang diceritakan kepadanya.

2) Menyukai olahraga.

3) Menyukai objek yang memiliki bentuk dan tekstur menarik.

4) Sering terjeda ketika berbicara.

5) Tidak banyak duduk diam dalam jangka waktu yang lama.

6) Menghafal dengan cara berjalan dan melihat.

7) Menggunakan jari sebagai penunjuk saat membaca (Wahyuni, 2017, p.130).

Setelah mengikuti pembelajaran jarak jauh, pengulangan materi bersama orang tua, dan mengerjakan tugas. Anak dapat mengalami bosan hingga stress karena melakukan rutinitas yang sama. Orang tua bisa memberikan kegiatankegiatan kreatif dan bermanfaat lainnya untuk menambah pengetahuan sang anak sekaligus menjalin komunikasi yang erat. Berikut ide kegiatan yang bisa dilakukan oleh orang tua dan anak :

a. Bermain

Bermain bersama anak akan menambah kedekatan anak dengan orang tua. Cara ini bisa menghilangkan bosan yang sedang dialami oleh anak. Kegiatan bermain ini bisa diarahkan ke arah edukasi. Misalnya bermain monopoli. Anak bisa mengetahui nama-nama negara yang belum dikunjunginya dan mengasah kemampuan anak berhitung dengan mengunakan dadu. Selain itu orang tua juga bisa mengajarkan anak untuk bermain secara jujur dan sportif.

b. Memasak

Kebanyakan orang tua malas untuk mengajak anaknya belajar memasak. Orang tua menganggap anak hanya akan menrusak peralatan masak dan membuat dapur menjadi kotor. Untuk menghindari hal ini, orang tua bisa membuat anak fokus pada apa yang akan dimasaknya. Contohnya orang tua akan memasak camilan untuk anak. Orang tua bisa menyuruh anaknnya untuk mengambilkan peralatan yang digunakan, membantu menakar tepung, membantu mencetak/membentuk adonan, dan lain-lain. Orang tua juga bisa menyelipkan pelajaran agama seperti dilarang untuk membuang makanan, bersyukur atas apa yang Allah berikan, dan semua yang ada di dunia ini seperti sayur dan buah itu semua tumbuh dikarenakan adanya kekuatan Allah. Kegiatan ini bisa lebih bermanfaat jika orang tua memiliki kreatifitas yang lebih dalam memberikan pengajaran yang berharga kepada anak. Hal yang perlu diwaspadai oleh orang tua adalah jangan meletakkan barang berbahaya seperti pisau di tempat yang dapat dijangkau oleh anak.

c. Membersihkan dan merapikan rumah

Kegiatan ini dapat menumbuhkan kedisplinan dan tanggung jawab pada anak. Anak juga bisa belajar cara menjaga kebersihan di sekitarnya. Orang tua bisa mengharahkan anak untuk membersikan kamar tidurnya, membereskan mainannya, melipat bajunya yang sudah kering, belajar menyapu, mencuci tangan, dan lain-lain.

d. Olahraga

Pembelajaran dari rumah terkadang membuat anak menjadi pemalas. Kerjaanya hanya berkutat pada handphone dan tugas. Bagi orang tua jangan lupa untuk mengajak 
anak olahraga di teras rumah. Kegiatan olahraga ini dapat membantu menjaga daya tahan tubuh anak agar kebal terhadap penyakit dan tetap sehat. Kegiatan olahraga ini bisa bemacam-macam sesuai kemampuan sang anak. Orang tua bisa mengajaknya untuk bermain lompat tali, push up, scout jam dan lain-lain. Apabila orang tua ingin mengajak anaknya untuk berolahraga di luar rumah agar tetap mematuhi protokol yang telah disepakati. Misalya tetap memakai masker dan selalu jaga jarak aman dengan orang lain.

e. Menggunakan aplikasi belajar gratis

Di dunia yang semakin modern ini banyak sekali aplikasi yang gratis ditawarkan oleh perusahaan yang bergerak teknologi. Aplikasi gratis ini bisa digunakan oleh orang tua untuk mengukur tingkat pemahaman anak mengenai materi terentu. Jadi orang tua bisa mengunduh aplikasi yang berkaitan dengan pelajaran anak.

f. Berkreasi lewat seni

Dalam pembelajaran anak cenderung dikonsentrasikan pada membaca dan menulis. Pembelajaran seperti ini hanya menggunakan otak kiri anak sehingga otak kanan anak sering tidak terpakai. Untuk mengasah otak kanan anak, orang tua bisa mengajarkan anaknya melukis, bermain cat warna, menyanyi, bermain alat musik dan menari. Aktivitas ini dapat meningkatkan keterampilan motorik, membangun rasa percaya diri, melatih imajinasinya dan pastinya membuat anak gembira.

g. Berkebun

Aktivitas berkebun dapat menambah pengalaman dan pengetahuan baru bagi anak. Dengan berkebun, anak bisa belajar untuk bertanggung jawab atas tanaman yang telah ia tanam, mencintai tumbuhan dan lingkungan serta mengenal berbagai macam tumbuhan.

h. Menonton film favorit

Mungkin orang tua tidak menganggap kegiatan ini berdampak positif bagi anak sehingga arang untuk dilakukan. Sebenarnya kegiatan ini berdampak positif jika kalian memilih film yang tepat bagi anak. Pilihlah film yang sesuai dengan usia sang anak, menghibur dan dapat diambil nilai positifnya. Orang tua juga bisa memilih film yang berbahasa asing. Ini akan menguji kemampuan mendengar anak. Anak harus dibiasakan untuk mendengar bahasa asing sehingga saat pembelajaran di sekolah menggunakan bahasa asing anak tidak syok dan tidak mengalami kesulitan yang berarti. Ingat, sesudah menonton film orang tua bisa menanyakan amanat (hal yang bisa diambil pelajarannya) dari film tersebut. Bila si anak tidak bisa menjawabnya, orang tua dapat menjelaskan apa yang ingin disampaikan pembuat film (produser) ke pada penontonnya (Nareza. Meva, 2020).

Kegiatan kreatif di atas, dapat disesuaikan dengan pembelajaran jarak jauh yang diampu oleh si anak. Kegiatan ini bisa diselipkan disela-sela waktu belajar anak sehingga dapat mengatasi kejenuhan dan anak tetap semangat mengikuti pembelajaran di rumah.

\subsubsection{Orang tua sebagai motivator}

Motivasi adalah dorongan untuk melakukan perubahan yang lebih baik dari sebelumnya yang diakibatkan oleh rangsangan dari dalam maupun dari luar. Peran orang tua sebagai motivator adalah memberikan rangsangan kepada anak yang malas belajar untuk lebih giat atau semangat dalam belajar. Pemberian motivasi kepada anak oleh orang tua dibagi menjadi dua yaitu :

a. Materi

Pemberian motivasi dalam bentuk materi dapat dilakukan dengan menyediakan fasilitas yang dibutuhkan kepada anak dalam belajar. Pemberian motivasi dalam bentuk materi ini sama dengan peran orang tua sebagai fasilitator yang telah dijelaskan di atas. Orang tua juga dapat memberikan hadiah atas kerja keras anak dalam belajar. Hadiah tersebut bisa berupa peralatan sekolah atau paket liburan buat anak pada musim liburan sekolah (Rumbewas et al., 2018, p.205).

b. Non materi

Motivasi dalam bentuk non materi yang bisa diberikan oleh orang tua kepada anak yaitu mendampingi anak ketika belajar, memberikan arahan tentang pentingnya belajar, dan memberikan pujian atas apa yang dilakukan anak. Pemberian pujian ini memang harus dilakukan setiap anak selesai mengerjakan sesuatu meskipun kadang pekerjaanya tidak sempurna atau kurang memuaskan. Hal ini dilakukan agar anak tetap semangat dan mau berusaha 
memperbaiki kekurangan atau kesalahannya.

\subsubsection{Orang tua sebagai Pengarah atau Director}

Orang tua memiliki tugas untuk selalu membimbing anaknya agar dapat mencapai kesuksesaan di masa depan dengan menemukan minat dan bakat yang dimiliki oleh sang anak (Winingsih. Endang, 2020). Dalam pencarian bakat dan minat anak, hal yang perlu dilakukan oleh orang tua adalah memberikan banyak pengalaman baru seperti kegiatan beraneka macam yang dicontohkan di atas atau bisa melakukan kegiatan lainnya. Dari kegiatan yang telah dilakukan, orang tua bisa mengamati ketertarikan anak pada kegiatan tersebut dan memulai untuk mengali lebih dalam minatnya yang dimilikinya.

\section{KESIMPULAN}

Dari paparan yang telah diuraikan, maka dapat disimpulkan bahwa peran orang tua sangat dibutuhkan untuk mendukung proses belajar di rumah agar berjalan efektif seperti pembelajaran di sekolah. Peran orang tua dalam membantu belajar di masa pandemi covid-19 terdiri dari 5 peran yaitu fasilisator, pedamping, guru atau pembimbing, motivator dan director atau pengarah. Kelima peran tersebut harus dijalankan oleh orang tua dengan baik. Sehingga pembelajaran di rumah menghasilkan pembelajaran yang bermanfaat dan dapat digunakan untuk meraih kesuksesan di masa depannya.

Dalam menjalankan kelima peran tersebut, orang tua diharapkan memiliki sifat sabar menghadapi tingkah laku anak, pantang menyerah dalam mencari jalan keluar yang efektif di setiap persoalan yang dihadapi serta berusaha yang terbaik untuk memberikan pembelajaran yang bermanfaat bagi anak.

\section{DAFTAR PUSTAKA}

Ahsan, Fadhil, Rahmawati Nanda Y \& Aldita F.N. (2020). Lawan Virus Corona : Studi Nutrisi untuk Kekebalan Tubuh. Jawa Timur : Airlangga University Press.

Ahsani, Eva Luthfi Fakhru. (2020). Strategi Orang Tua dalam Mengajar dan Mendidik
Anak dalam Pembelajaran At The Home Masa Pandemi Covid-19. Al-Athfal, 3 (1), 143.

Arianti. (2017). Urgensi Lingkungan Belajar yang Kondusif dalam Mendorong Siswa Belajar Aktif. Didaktika, 11(1), 61.

Arnani, Melani. (2020). Penjelasan Soal Sifat, Bentuk dan Cara Virus Corona Menginfeksi Manusia. Kompas. Diakses melalui

https://www.kompas.com/tren/read/2020/ 03/22/083000665/penjelasan-soal-sifatbentuk-dan-cara-virus-coronamenginfeksi-manusia?page $=$ all

Dini. (2020). 4 Gaya Belajar Anak dan Bagaimana Mengarahkannya. Diakses pada tanggal 23 Juli 2020 melalui https:// www.ibupedia.com/artikel/balita/gayabelajar-anak-dan-bagaimanamengarahkannya

Handayani, D., Hadi, D. W., Isbaniya, F., Burhan, E., \& Agustin, H. (2020). Penyakit Virus Corona 2019. Respirologi Indonesia 40(1), 122.

Hermawan, Iwan. Metode Penelitian Pendidikan : Kuantitatif, Kualitatif dan Mixed Metode. Jawa Barat : Hidayatul Qur'an Kuningan.

Ihsanuddin. (2020). Fakta Lengkap Kasus Pertama Virus Corona di Indonesia. Kompas. Diakes melalui https://nasional.kompas.com/read/2020/03 /03/06314981/fakta-lengkap-kasuspertama-virus-corona-diindonesia?page $=$ all

Kemendikbud (2020). Sikapi Covid-19, Kemendikbud Terbitkan Dua Surat Edaran. Menteri Pendidikan dan Kebudayaan. Diakses melalui : www.kemendikbud.go.id

Nareza, Meva. (2020). Tips agar Anak Tidak Bosan di Masa pandemi Covid-19. Diakes pada tanggal 24 Juli 2020 melalui https://www.alodokter.com/tips-agaranak-tidak-bosan-di-rumah-selamapandemi-covid-19

Redaksi. (2020). Kilas Balik Pandemi covid-19, 31 Desember 2019-31 Maret 2020. DARILAUT.ID. Diakses pada tanggal 13 juni 2020 melalui : https://darilaut.id/berita/kilas-balikpandemi-covid-19-31-desember-2019-31maret-2020

Rezkisari, Indra.(2020). Belajar dari Rumah, Kosep yang Ternyata tak Mudah. Diakses 
pada tanggal 1 Juli 2020 melalui https://m.republika.co.id/berita/q7ds3032 8/belajar-dari-rumah-konsep-yangternyata-tak-mudah

Rumbewas, Selfia S., Laka Beatus M., \& Moekbun Naftali. (2018). Peran Orang Tua dalam Meningkatkan Motivasi Belajar Peserta Didik di SD Negeri Saribi. EduMatSains, 2(2), 205.

I Made Indra P \& Cahyaningrum, Ika. (2020). Cara Mudah Memahami Metode Penelitian. Yogyakarta : CV Budi Utama.

Surat Edaran Nomor 15 Tahun 2020 tentang Pedoman Penyelenggaraan Belajar dari Rumah Dalam Masa Darurat Penyebaran Corona Virus Desease (Covid-19).

Taufiq, Ali. (2019). Perspektif tentang Perkembangan Sistem Jarak Jauh di Kabupaten Kutai Kartanegara Kalimantan Timur. Pendidikan : Riset dan Konseptual, 3(2), 88.

Wahyuni, Yusri. (2017). Identifikasi Gaya Belajar (Visual, Auditorial, Kinestetik) Mahasiswa Pendidikan Matematikan Universitas Bung Hatta. JPPM, 2(1), 130.

Wibowo, wahyu. (2011). Cara Cerdas Menulis Artikel Ilmiah. Jakarta : PT Kompas Media Nusantara

Widayanti, Febi Dwi. (2020). Pentingnya Mengetahui Gaya Belajar Siswa dalam Kegiatan Pembelajaran di Kelas. Erudio, 2(1), 10.

Winingsih, Edang. (2020). Peran Orang Tua dalam Pembelajaran Jarak Jauh. Diakses pada tanggal 1 Agustus 2020 melalui https://poskita.co/2020/peran-orang-tuadalam-pembelajaran-jarak-jauh

Yuliana. (2020). Corona Virus Disease (Covid19); Sebuah Tinjauan Literatur. Wellness and Healthy Magazine, 2(1), 187. 